\title{
Development of Decision Support System to Selection of the Blended Learning Platforms for Mathematics and ICT Learning at SMK TI Udayana
}

\author{
I Made Ardana ${ }^{1}$ \\ Mathematics Education \\ Universitas Pendidikan Ganesha \\ Bali, Indonesia
}

\author{
I Putu Wisna Ariawan ${ }^{2}$ \\ Mathematics Education \\ Universitas Pendidikan Ganesha \\ Bali, Indonesia
}

\author{
Dewa Gede Hendra Divayana ${ }^{3}$ \\ Education of Information Technology \\ Universitas Pendidikan Ganesha \\ Bali, Indonesia
}

\begin{abstract}
The development of information technology is able to solve problems in various areas of life, including education. Some examples of the application of information technology in education, among others: e-learning, e-library, e-module, blended learning, and more. One school in Bali that also apply information technology in the learning process, namely SMK TI Udayana. Application forms of information technology in the learning process at SMK TI Udayana have the shape of utilization of blended learning. There are several platforms options can be used for blended learning in the learning process at SMK TI Udayana, including: Edmodo, Quipper School, Moodle, Kelase, and others. Facts show that the number of platforms that can be used for blended learning, sometimes making teachers and students get confused to choose the most suitable, especially in the process of mathematics and ICT learning at SMK TI Udayana. Based on these problems, then created of the decision support system to be able to choose a blended learning platforms that is suitable for mathematics and ICT learning at SMK TI Udayana. The methods used in this decision support system is weighted product, because it can determine blended learning platforms for mathematics and ICT learning based on the highest value obtained from the calculation of several criteria.
\end{abstract}

Keywords-Blended Learning; Decision Support System; Weighted Product; Mathematics and ICT Learning

\section{INTRODUCTION}

The development of information technology is able to solve problems in various areas of life, such as agriculture, medicine, pharmacy, economics, and including also the field of education. Some examples of the application of information technology in education, among others: e-learning, e-library, e-module, blended learning, and more. One school in Bali that also apply information technology in the learning process, namely SMK TI Udayana. Application forms of information technology in the learning process at SMK TI Udayana have the shape of utilization of blended learning. There are several platforms options can be used for blended learning in the learning process at SMK TI Udayana, including: Edmodo, Quipper School, Moodle, Kelase, and others. Facts show that the number of platforms that can be used for blended learning, sometimes making teachers and students get confused to choose the most suitable, especially in the learning process of Mathematics and ICT learning at SMK TI Udayana. That is because the characteristics of mathematics and ICT different from other subjects. Math and ICT are more likely to sample questions that require a lot of facilities quiz, while the other subjects may be a lot of explaining concepts, thus requiring more space to display material.

Based on these problems, then made a decision support system to be able to choose a blended learning platforms that is suitable for the Mathematics and ICT learning at SMK TI Udayana.

\section{LITERATURE REVIEW}

\section{A. Decision Support System}

In [1], Decision Support System is an interactive computer-based system that helps decision makers to utilize data and models to solve unstructured problems.

In [2], Decision Support System is an interactive, flexible, and adaptable computer-based information system, especially developed for supporting the solution of a non-structured management problem for improved decision making.

In [3], Decision Support System is a computer-based system that aids the process of decision making.

In [4], Decision support systems can aid human cognitive deficiencies by integrating various sources of information, providing intelligent access to relevant knowledge, and aiding the process of structuring decisions.

Based on some views above, a synthesis can be generally made that decision support systems is computer-based system used to solve unstructured problems based on specific criteria and integrated with a variety of resources so as to produce the optimal decision.

\section{B. Blended Learning}

In [5], Blended learning is a student-centered approach to creating a learning experience whereby the learner interacts with other students, with the instructor, and with content through thoughtful integration of online and face-to-face environments.

In [6], Blended learning is a strategic and systematic approach to combining times and modes of learning, integrating the best aspects of face-to-face and online interactions for each discipline, using appropriate ICTs. 
In [7], Definitions of blended learning range from the very broad where practically any learning experience that integrates some use of ICTs qualifies, to others that focus on specific percentages of online curriculum and face to face instruction. Most people agree that blended learning combines teaching and learning methods from face to face, mobile and online learning and that it includes elements of both synchronous and asynchronous online learning options.

In [8], blended learning is a formal education program in which a student learns: (1) at least in part through online learning, with some element of student control over time, place, path, and/or pace; (2) at least in part in a supervised brick-and-mortar location away from home; (3) and the modalities along each student's learning path within a course or subject are connected to provide an integrated learning experience.

In [9], blended learning is the interdependent combination of face-to-face and online education. It involves combining the better of these two modes of learning in such a way that they complement and supplement each other. Effective blended learning occurs when online and face-to-face modalities are used to their full advantage for optimal interaction and when there is capacity for student-paced and student-directed learning.

In [10], blended Learning has been defined in a variety of ways in the current specialized literature. The most common and current definition states that blended learning combine face-to-face instruction with distance education delivery systems.

Based on some views above, a synthesis can be generally made that Blended Learning is a student-centered learning using a systematic approach that combines face-to-face learning and online learning aided by ICTs.

\section{Weighted Product}

In [11], one way of partially avoiding the influence of the normalization procedure on the final result is to use the weighted product method, whose principle is close to that of the weighted sum. Values are multiplied instead of added, and each alternative being evaluated as follows:

$$
P_{\left(a_{i}\right)}=\left(a_{i 1}{ }^{w_{1}}\right) *\left(a_{i 2} w_{2}\right) * \ldots, \ldots\left(a_{i n}{ }^{w_{n}}\right)=\pi_{j}\left(a_{i j}{ }^{w_{j}}\right)
$$

In [12], Weighted Product Method use multiplication to connect the attribute ratings, where the ratings of each attribute must be raised first with the relevant attribute weights. This process is similar to the process of normalization. Preferences for alternative $A_{i}$ is given as follows:

$$
S_{i}=\prod_{j=1}^{n} x_{i j}{ }^{w_{j}} \quad \text { with } \mathrm{i}=1,2, \ldots, \mathrm{n} \text { and } \mathrm{w}_{\mathrm{j}}=1
$$

$\mathrm{w}_{\mathrm{j}}$ is the power of positive value to attribute profits, and is negative for the cost attribute. Relative preference of each alternative, given as:

$$
V_{i}=\frac{\Pi_{i}^{n}=1 x_{i j}{ }^{w / j}}{\|_{j}^{n}=1\left(x_{j^{*}}\right)^{w_{j}}} \quad \text { with } \mathrm{i}=1,2, \ldots, \mathrm{n}
$$

$\mathrm{V}$ : Preferences alternatives considered as a vector $\mathrm{V}$

$\mathrm{x}$ : Value of Criteria

w : Weight of Criteria / Sub-criteria

i : Alternative

j : Criteria

$\mathrm{n}$ : number of criteria

\section{METHODOLOGY}

\section{A. Object and locations of the study}

1) The object of the study was platforms of blended learning.

2) The locations were SMK TI Udayana in Mengwi, Bali.

\section{B. Subject of the Study}

The subjects of the study were 10 teachers in SMK TI Udayana.

\section{Type of Data}

The data in this study were quantitative data.

\section{Technique of data collection}

The data were collected through observation and questionnaire.

\section{E. Technique of Data Analysis}

The data of the study were analyzed descriptively.

\section{RESULT AND DISCUSSION}

\section{A. Result}

\section{1) Blended Learning Platform}

Some choice for blended learning platform that can be used in the process of mathematics and ICT learning at SMK TI Udayana, among others:

\section{a) Edmodo}

In [13], Edmodo is a global education network that helps connect all learners with the people and resources needed to reach their full potential. Edmodo can be seen at https://www.edmodo.com/

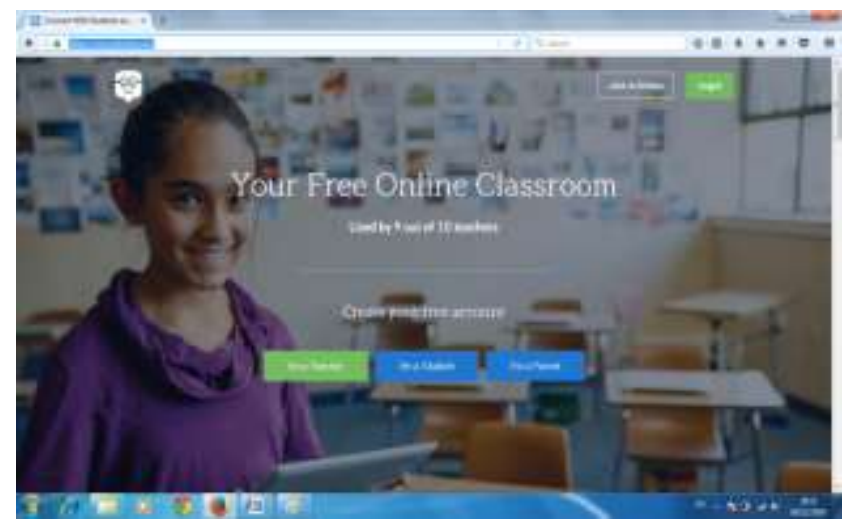

Fig. 1. Edmodo Platform

\section{b) Quipper School}

In [14], Quipper School is a FREE online platform for teachers and students. Quipper School consists of two parts: LINK for teachers, and LEARN for students. Quipper School 
Link is where teachers manage their classes online and check students' progress. Quipper School Learn is where students study. It's packed with features that make learning safe and fun. Quipper School can be seen at https://school.quipper.com/en-PH/

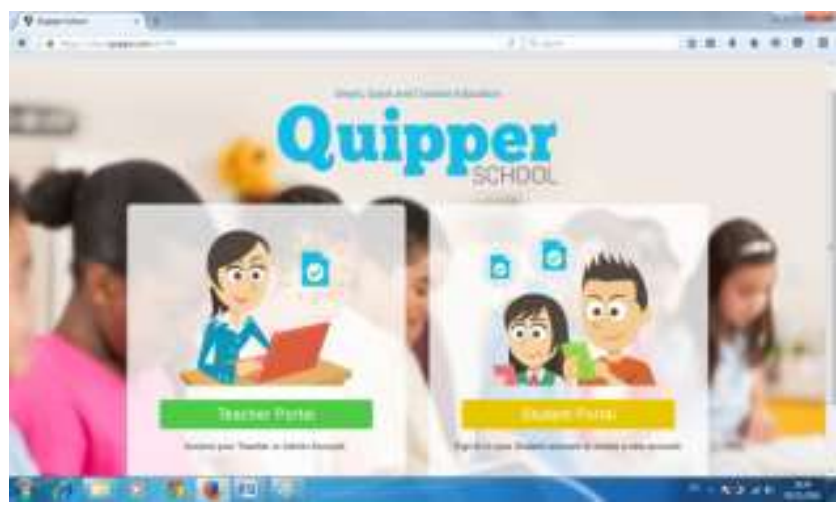

Fig. 2. Quipper School Platform

\section{c) Moodle}

In [15], Moodle is a learning platform designed to provide educators, administrators and learners with a single robust, secure and integrated system to create personalized learning environments. Moodle can be seen at https://moodle.org/

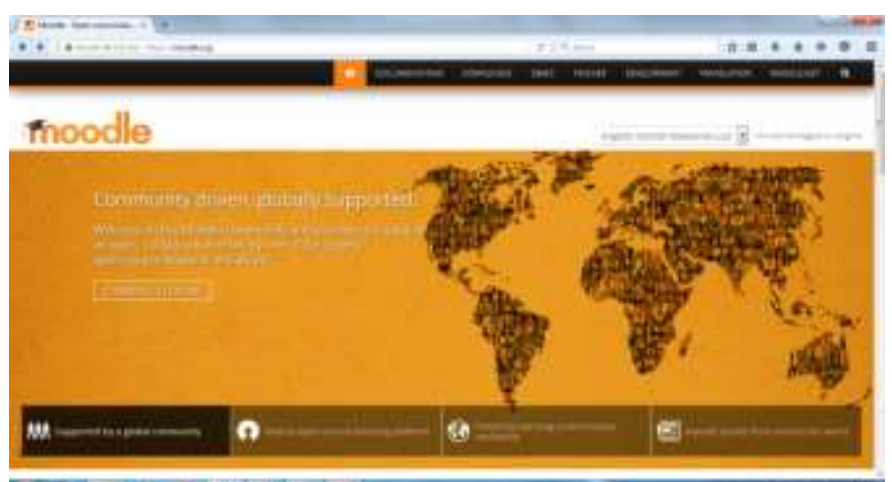

Fig. 3. Moodle Platform

\section{d) Kelase}

In [16], Indonesia's online education space just got another boost of confidence today as Kelase, a private social network for education, received an undisclosed amount seed funding from PT Insights Investments, a financial and investment firm in Indonesia. The money will be used for Kelase's product development, recruitment, and system maintenance. Kelase rolled out its trial version on June 2014. The startup allows education institutions to have their own social networks. Teachers and students can store and share numerous files on Kelase including education videos, e-books, and academic calendars some of which Kelase itself provides. Kelase can be seen at http://www.kelase.com/

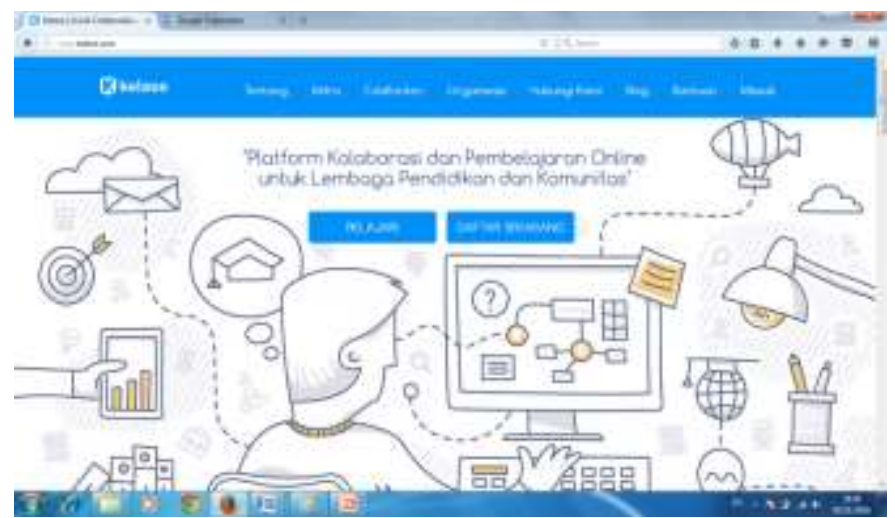

Fig. 4. Kelase Platform

2) Results of selection the Blended Learning Platform through calculation Weighted Product Method

Results of selection the Blended Learning Platform for Mathematics and ICT learning at SMK TI Udayana through calculation Weighted Product methods can be seen in Table I below.

TABLE I. RESUlTS OF SELECTION THE BLENDED LEARNING PLATFORM FOR MATHEMATICS AND ICT LEARNING AT SMK TI UDAYANA

\begin{tabular}{|l|c|c|c|c|}
\hline \multirow{2}{*}{\multicolumn{1}{c|}{ Platforms }} & \multicolumn{4}{c|}{ Criterion } \\
\cline { 2 - 5 } & C1 & C2 & C3 & C4 \\
\hline Edmodo & 84 & 85 & 86 & 84 \\
\hline Quipper School & 85 & 86 & 80 & 84 \\
\hline Moodle & 82 & 81 & 86 & 85 \\
\hline Kelase & 85 & 84 & 83 & 84 \\
\hline
\end{tabular}

Note:

C1: easy to used

C2: attractive display

C3: large data capacity

C4: completed facilities

The weight for making a decision for each criterion is as follows.

C1: 5

$\mathrm{C} 2: 4$

C3: 4

C4: 4

The complete weighted product calculation to obtain the decision result can be explained as follows.

First a correction of weight is done such as $\sum \mathrm{w}=1$. Thus, it is obtained that $\mathrm{w}_{1}=0.2941 ; \mathrm{w}_{2}=0.2353 ; \mathrm{w}_{3}=0.2353$; and $\mathrm{w}_{4}=0.2353$.

Category of each criteria:

$>$ Criterion $\mathrm{C}_{1}$ is an advantage criterion.

$>$ Criterion $\mathrm{C}_{2}$ is an advantage criterion.

$>$ Criterion $\mathrm{C}_{3}$ is an advantage criterion.

$>$ Criterion $\mathrm{C}_{4}$ is an advantage criterion.

Then vector $\mathrm{S}$ can be calculated as folows:

$S_{1}=\left(84^{0.2941}\right)\left(85^{0.2353}\right)\left(86^{0.2353}\right)\left(84^{0.2353}\right)=84.702$
$S_{2}=\left(85^{0.2941}\right)\left(86^{0.2353}\right)\left(80^{0.2353}\right)\left(84^{0.2353}\right)=83.793$ 
$S_{3}=\left(82^{0.2941}\right)\left(81^{0.2353}\right)\left(86^{0.2353}\right)\left(85^{0.2353}\right)=83.387$

$S_{4}=\left(85^{0.2941}\right)\left(84^{0.2353}\right)\left(83^{0.2353}\right)\left(84^{0.2353}\right)=84.056$

The value of vector $\mathrm{V}$ to be used for ranking can be calculated as follows.

$$
\begin{aligned}
& V_{1}=\frac{84.702}{84.702+83.793+83.387+84.056}=0.252 \\
& V_{2}=\frac{83.793}{84.702+83.793+83.387+84.056}=0.249 \\
& V_{3}=\frac{83.617}{84.702+83.793+83.387+84.056}=0.248 \\
& V_{4}=\frac{84.056}{84.702+83.793+83.387+84.056}=0.250
\end{aligned}
$$

Based on the calculation of the vector $\mathrm{V}$ obtained the greatest value that is at $\mathrm{V}_{1}$ by 0.252 . The visualization of calculation can also be demonstrated by the following application program.

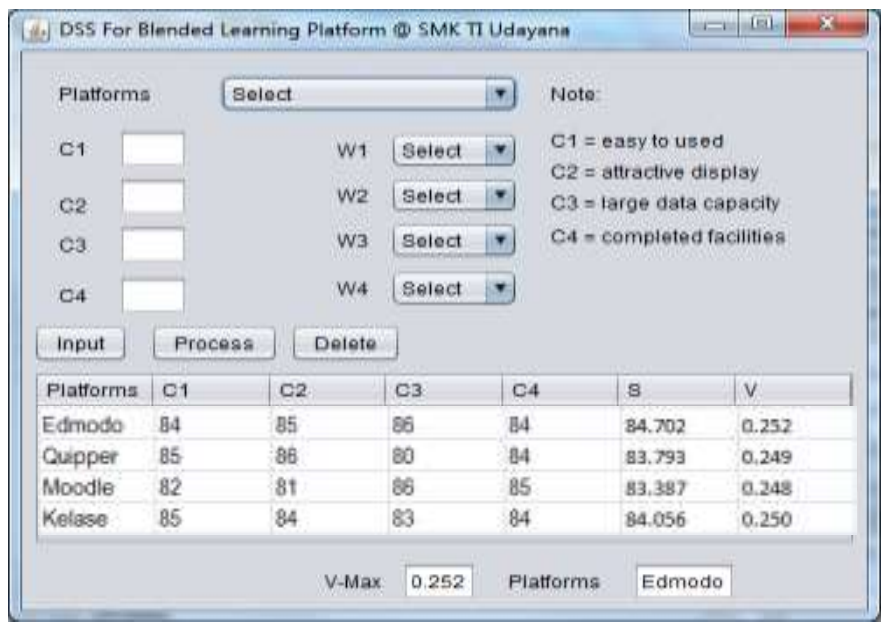

Fig. 5. DSS For Blended Learning Platform at SMK TI Udayana

\section{B. Discussion}

Based on the results of the study there were four blended learning platform that is offered for use in the process of mathematics and ICT learning at SMK TI Udayana, among others: Edmodo, Quipper School, Moodle and Kelase.

Calculation of the weighted product method based on inputted values into the four criteria. The calculations show the results of the largest-value vector $\mathrm{V}=0.252$, located at $\mathrm{V}_{1}$, so Edmodo chosen as the blended learning platforms in mathematics and ICT learning at SMK TI Udayana.
Development of decision support system to selection the blended learning platforms for Mathematics and ICT Learning at SMK TI Udayana visualized using the Java programming language and MySQL database.

\section{CONCLUSIONS}

Based on the results of research and discussion, we can conclude that the blended learning platforms that is selected to facilitate the learning process of Mathematics and ICT at SMK TI Udayana is Edmodo, because it is based on the calculation of Weighted Product got the highest achievement when compared to other platforms.

\section{REFERENCES}

[1] R.H. Sprague, and E.D. Carlson, Building Effective Decision Support Systems. Englewood Clifts, N.J.: Prentice-Hall, Inc., 1982.

[2] P.N. Finlay, Introducing Decision Support Systems. Oxford, UK Cambridge, Mass., NCC Blackwell; Blackwell Publishers, 1994.

[3] E. Turban. 1995. Decision Support and Expert Systems: Management Support Systems. Englewood Cliffs, N.J.: Prentice Hall, 1995.

[4] M.J. Druzdzel, and R. R. Flynn, Decision Support Systems. Pittsburgh, Pennsylvania, U.S.A.: Taylor \& Francis, 2010.

[5] R. Garrison and H. Kanuka, "Blended Learning: Uncovering its Transformative Potential in Higher Education," Internet and Higher Education 7, 2004, pp. 95-105.

[6] G. Saliba, L. Rankine, and H. Cortez, Fundamentals of Blended Learning. Sydney: University of Western Sydney, 2013.

[7] Department of Education and Early Childhood Development. Blended Learning: A Synthesis of Research Findings in Victorian Education 2006-2011. Melbourne: NEALS, 2012.

[8] http://www.christenseninstitute.org/blended-learning-definitions-andmodels/

[9] https://bond.edu.au/about-bond/academia/learning-teaching/blendedlearning

[10] R. T. Osguthorpe, and C. R. Graham, C.R, "Blended learning environments: Definitions and directions," The Quarterly Review of Distance Education, Vol. 4, No. 3, 2003, pp. 227-233.

[11] J. C. Pomerol, and S.B. Romero, Multicriterion Decision in Management: Principles and Practice. New York: Kluwer Academic Publishers, 2000.

[12] D.G. Hendra Divayana, "Development of Duck Diseases Expert System with Applying Alliance Method at Bali Provincial Livestock Office," International Journal of Advanced Computer Science and Applications, Vol. 5, No. 8, 2014, pp. 48-54.

[13] https://www.edmodo.com/about

[14] https://help.quipper.com/en/article_groups/access-codes/articles/what-isquipper-school

[15] https://docs.moodle.org/31/en/About_Moodle

[16] https://www.techinasia.com/kelase-indonesia-seed-funding-educationsocial-network 